\title{
Novelties in the family Acanthaceae from South Western Ghats, India
}

Jose Mathew ${ }^{1 *}$, Regy Yohannan ${ }^{2}$, P.M.Salim ${ }^{3}$ and K.V.George ${ }^{4}$

${ }^{1}$ School of Environmental Sciences, Mahatma Gandhi University, Kottayam, Kerala, India.

${ }^{2}$ Department of Botany, SN College, Kollam, Kerala, India.

${ }^{3}$ M.S. Swaminathan Research Foundation, Pothoorvayal, Wayanad, Kerala, India.

${ }^{4}$ Department of Botany, SB College, Changanassery, Kerala, India.

Received: December 16, 2016; Accepted: December 30, 2016

\begin{abstract}
Within the context of the floristic study of the family Acanthaceae from south Western Ghats, one new species, Strobilanthes philipmathewiana J.Mathew \& Yohannan is described. In addition, a new combination, Hygrophila auriculata (K.Schum.) Heine var. alba (Parmar) P.M.Salim, J.Mathew \& Yohannan, and substantiate the occurrence of Asystasia variabilis (Nees) Trimen in India are made here. Their taxonomic description, morphological differences to their allied taxa and colour photographs are provided to facilitate easy identification in the field.
\end{abstract}

Key words: Acanthaceae; Asystasia variabilis; Hygropbila auriculata var. alba; new species; Strobilanthes philipmathewiana

\section{Introduction}

The southern Western Ghats, situated at the crossroads of the Indian peninsula and South Asia, is considered a significant biogeographical hotspot area of the world. It has a unique status as an ancestral area holding varied concentrations of endemic species. Botanical explorations in southern Western Ghats during 2010-2016 have yielded some interesting specimens of the family Acanthaceae. This has resulted as some novelties in the flora of south Western Ghats as follows.

1. Strobilanthes philipmathewiana J.Mathew \& Yohannan, sp. nov.

The genus Strobilanthes Blume comprises about 450 species (Mabberley, 2005) mainly distributed in tropical Asia and Australia. According to Karthikeyan et al., (2009), 146 species of Strobilanthes have been recorded from India and 43 species from Kerala (Sasidharan, 2013). Botanical explorations in the Vellarimala forests of southern Western Ghats during 20142015 yielded- specimens of Strobilanthes that we feel are sufficiently distinctive to warrant taxonomic recognition as a new species. Strobilanthes philipmathewiana is here described and illustrated.

Strobilanthes philipmathewiana J.Mathew \& Yohannan, sp. nov.

Diagnosis: Strobilanthes philipmathewiana resembles Strobilanthes kuntbianus (Nees) Anders. ex Benth., but differs by its large shrubby, tomentose and woody habit, winged stem, auricled petiole, short unbranched spike of 2-4 cm, wine red coloured bract and straight corolla tube with glabrous and wavy margins of corolla. S. philipmathewiana is also morphological similar, with similar ecological preferences to those of Strobilanthes sessilis Nees var. sessilis Hook. f. and Strobilanthes sessilis Nees var. sessiloides (Wight) Clarke, but differs from these species as indicated in Table 1.

Erect shrubs, ca $2 \mathrm{~m}$ high; stems tetragonous, winged, densely cottony-tomentose, nodes swollen, jointed. Leaves opposite, ca 2.5-4 x 1.5-2.5 cm, elliptic-lanceolate, from an acute base tapering into petiole, serrate at margin, acute or acuminate at apex, brownish in colour, silky or tawny woolly upper and lower surfaces; lateral nerves 8-10 pairs, venation compound, recti-pinnate, impressed above, prominent below; petioles winged, $0.5-0.7 \mathrm{~cm}$ long, dense-tomentose. Inflorescence spikes, axillary or terminal, usually single, rarely basally branched, $2-4 \mathrm{~cm}$ long, with grey or tawny wool; bracts ovate or lanceolate, wine red coloured, acute, ca $1 \mathrm{~cm}$ long, tomentose outside, glabrous and shining inside; bracteoles linear-oblong, ca $1 \mathrm{~cm}$ long, tomentose outside, glabrous inside. Calyx ca $0.7-.9 \mathrm{~cm}$ long; tube ca $2 \mathrm{~mm}$ long; lobes linear, equal, pubescent outside, glabrous and shining dark violet inside. Corolla ca $2.5-3 \mathrm{~cm}$ long, pale blue; tube not curved, ca $9 \mathrm{~mm}$ long, gradually widening above, ca $1.9-2.4 \mathrm{~cm}$ long, 5-lobed; lobes wavy, ovate, ca $4 \mathrm{~mm}$. Stamens 4; filaments ca $1.5 \mathrm{~cm}$ long, included, very hairy. Ovary ca $2 \mathrm{~mm}$ long, hairy above; style linear, ca $1.3 \mathrm{~cm}$ glabrous; stigma oblique. Capsules not found. Fig.1

Table 1: Prominent morphological differences between Strobilanthes philipmathewiana with its allied taxa

\begin{tabular}{|c|c|c|c|c|}
\hline Characters & S. philipmathewiana & S. kunthianus & S. sessilis var. sessilis & S. sessilis var sessiloides \\
\hline Habit & shrubs, to $2 \mathrm{~m}$ & bushy, to $0.7 \mathrm{~m}$ & shrubs, to $1 \mathrm{~m}$ & shrubs, to $1 \mathrm{~m}$ \\
\hline Stem & $\begin{array}{l}\text { winged, } \\
\text { tomentose }\end{array}$ & $\begin{array}{l}\text { not winged, } \\
\text { glabrous }\end{array}$ & $\begin{array}{l}\text { not winged, } \\
\text { tomentose }\end{array}$ & $\begin{array}{l}\text { not winged, } \\
\text { tomentose }\end{array}$ \\
\hline Petiole & auricled & not auricled & not auricled & not auricled \\
\hline Leaf shape & elliptic-lanceolate & elliptic & ovate & ovate \\
\hline Leaf base & attenuate & obtuse & subcordate & subcordate \\
\hline Leaf surface & glandular hairy & glabrous & glandular hairy & glandular hairy \\
\hline Inflorescence & $\begin{array}{l}\text { unbranched or } \\
\text { rarely basally branched }\end{array}$ & branched & branched & branched \\
\hline Bracts & wine red colour & green & green, red tinge in apex & green \\
\hline Corolla tube & straight & curved & straight & straight \\
\hline Corolla lobe & wavy & entire & entire & entire \\
\hline
\end{tabular}

Type: INDIA, Western Ghats, Kerala, Kozhikode District, REC Para, altitude 1950 m, 5 November 2014, J.Mathew 4176 (holo: MSSRF!; iso: SESH!).

\section{${ }^{*}$ Corresponding Author:}

Dr. Jose Mathew,

School of Environmental Sciences,

Mahatma Gandhi University, Kottayam, Kerala, India.

E-mail: polachirayan@yahoo.co.in

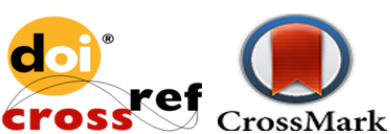



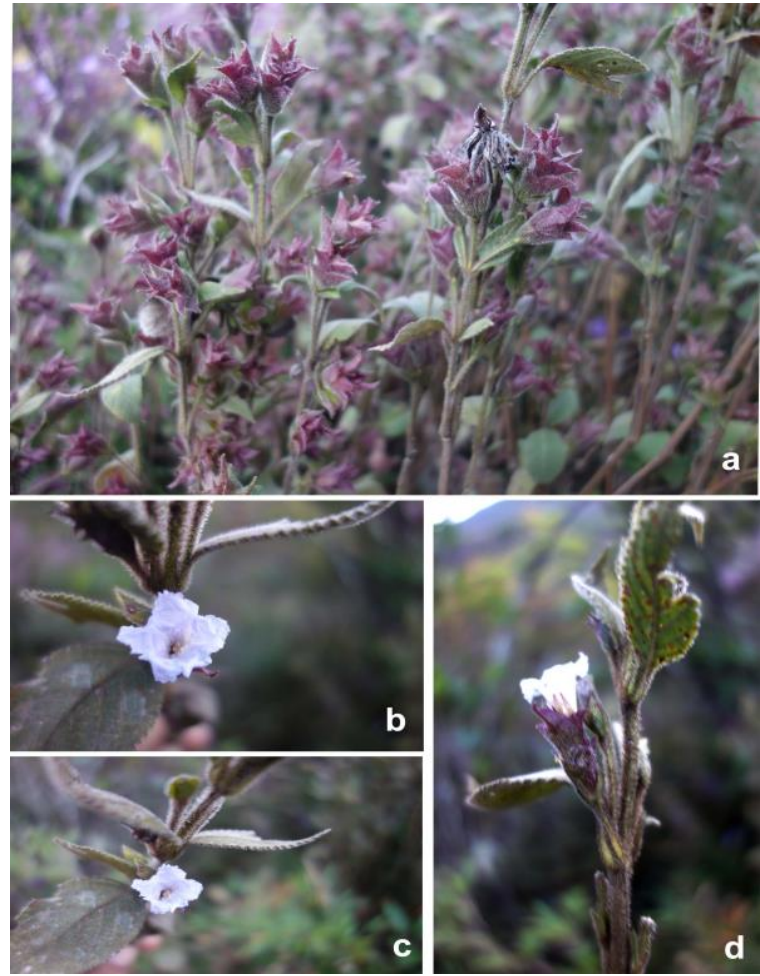

Fig. 1: Strobilanthes philipmathewiana J.Mathew \& Yohannan: a. Plants in natural habitat; b \& c. Flowering twigs; d. Inflorescence side view. Photographed by J.Mathew

Other specimen examined: India: Kerala: S Western Ghats, Kozhikode district, Kanjippara, 9 January 2016, J.Mathew 4699, 4700 (SESH, Mahatma Gandhi University, Kottayam, Kerala).

Etymology: The specific epithet honours Dr. Philip Mathew, Professor of Botany (Retd.), University of Calicut, Kerala, and recognizes his immense contributions to botany, especially in the fields of angiosperm biodiversity and taxonomy.

Distribution and ecology: Strobilanthes philipmathewiana is endemic to the Southern Western Ghats, currently known only from two localities from Vellarimala in the Kozhikode District. The species grows in evergreen forests at altitudes of ca. $1800 \mathrm{~m}$ in association with Strobilanthes rubicundus (Nees) Anders, Clematis smilacifolia Wall., Lobelia leschenaultiana (Presl) Skottsb. and Meineckia longipes (Wight) Webster.

Flowering: November-February

Conservation status: This new species is currently known only from 2 localities of REC Para region of Vellarimala, each separated by $100 \mathrm{~m}$. A total of 90 mature individuals were found in the area. The data gained from the field studies were evaluated according to the IUCN (2012) categorization and at least "vulnerable" status has been proposed for the species.

\section{Hygrophila auriculata (K. Schum.) Heine} var. alba (Parmar) P.M. Salim, J.Mathew \&

Yohannan comb. nova.

Hygrophila R. Br., a swamp weed genus comprising ca. 100 species distributed across the tropical and subtropical world (Jiaqi et al., 2009). According to Karthikeyan et al., (2009), 24 taxa of Hygrophila have been recorded in India, of which, 5 taxa viz., Hygrophila balsamica (L.f.) E.Hossain, H. ringens (L.) R. Br. ex Spreng., H. ringens R.Br. subsp. longifolium J.Mathew \& Kad.V.George, H. auriculata (Schumach.) Heine and H. triflora (Roxb.) Fosb. \& Sachet are recorded from the Kerala, part of southern Western Ghats (Sasidharan, 2013; Mathew \& George, 2013). Among those plants, H. auriculata, a spectacular medicinal plant is distinguished by its characteristic thorns and strigose hispid leaves / stems. Botanical explorations in the Wayanad forests during 2012-2015 have yielded some interesting specimens of $H$. auriculata. Critical analysis of the literature as well as of herbarium specimens revealed that some of them belonging to an impressive variety of Hygrophila auriculata (K. Schum.) Heine, and it represents the rediscovery of Van Rheed's White' Babell schulli from Malabar after 330 years.

Table 2: Characteristics that separate Hygrophila auriculata var. alba from Hygrophila auriculata

\begin{tabular}{|c|c|c|}
\hline $\begin{array}{l}\text { Character } \\
\text { Leaf }\end{array}$ & H. auriculata & H. auriculata var. alba \\
\hline number & 8 leaves in a whorl & 6 leaves in a whorl \\
\hline & $6-10 \times 2-4 \mathrm{~cm}$ & $10-20 \times 0.9-1.2 \mathrm{~cm}$ \\
\hline margins colour & violet colorations & light green \\
\hline Stem & & \\
\hline shape & quadrangular & imperfectly quadrangula \\
\hline internode length & $4-6 \mathrm{~cm}$ & $3-3.6 \mathrm{~cm}$ \\
\hline colour & red & green \\
\hline Flower & & \\
\hline colour & purple to pink & white \\
\hline $\begin{array}{l}\text { hairs in acanth- } \\
\text { aceous mark }\end{array}$ & $1 \mathrm{~mm}$ & $3 \mathrm{~mm}$ \\
\hline
\end{tabular}
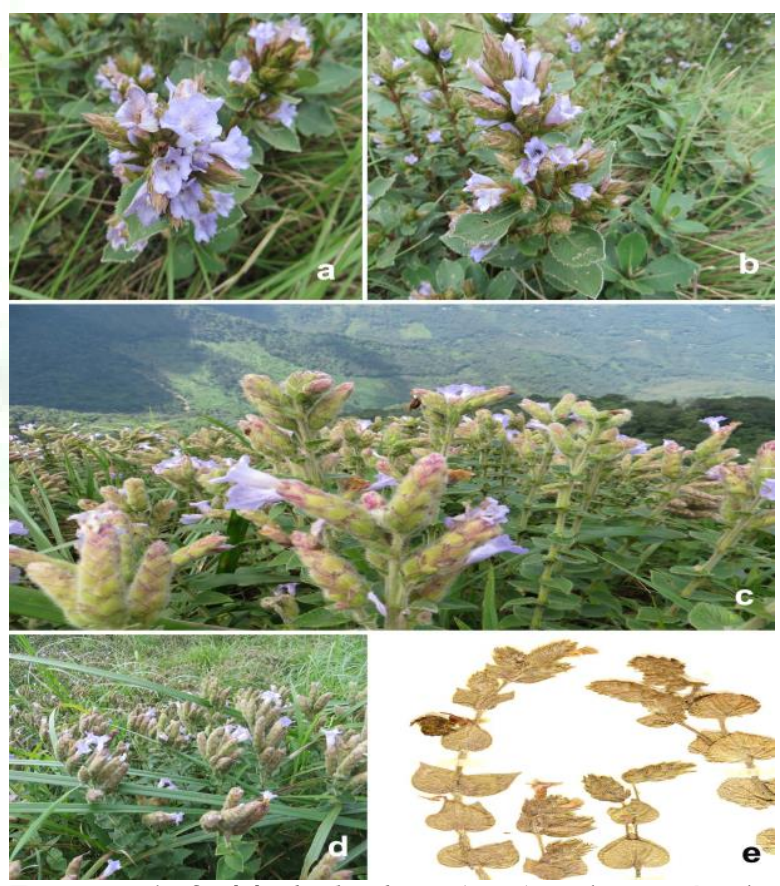

Fig. 2: a \& b. Strobilanthes kunthianus (Nees) Anders. ex. Benth.; c \& d. Plants Strobilanthes sessilis Nees var. sessilis Hook. f.; e. Strobilanthes sessilis Nees var. sessiloides (Wight) Clarke. Photographed by J.Mathew 
Van Rheede (1636-1691), the Dutch Admiral of Malabar realized Malabar as the land of spices and medicinal plants and took interest to collect and document the plant wealth of Malabar. The first assortment of 'White' Babell schulli was appeared in his second volume of Hortus Malabaricus (Rheede, 1679). He wrote "there is yet another species of Babel schull, growing in sandy soil which have stalk and leaves light green and not red, but white flowers, somewhat bordering on blue" (Manilal, 2003).

Thereafter, this species remained unknown until it was rediscovered from the Nandur Madhmeshwar Sanctury, Nasik, Maharashtra (Almeida \& Almeida, 1986) and Mehsana district in north Gujarat (Parmar, 2008) after 300 years. Parmer ranked this taxon as a variety of $H$. schulli and named as $H$. scbulli (Buch. -Ham.) M. R. \& S. M. Almeida var. alba parmer. He distinguished it from typical $H$. schulli by its pure white flowers and light green leaves.

Later, Hygrophila scbulli var. alba was reduced to synonymy of $H$. schulli without proper investigation of the type material. In the most recent treatment of the genus Hygrophila, variety alba as belonging to $H$. schulli was continued (Roskov et al., 2014). A critical examination of types and other materials of $H$. scbulli var. alba and Hygrophila scbulli coupled with the materials collected from Wayanad and field observations showed that the former has a distinct warrant to be a good and individual variety. Thus, we argue that Parmer (2008) was correct in treating Hygropbila schulli var. alba as a distinctive variety, and which should be reinstated.

But there is an ambiguity still remains in the naming of this taxa. Because, M.R. Almeida \& S.M. Almeida (1986) intended H. schulli as a new combination based on "Babel schulli Buch. Ham., Trans. Linn. Soc. London 14:289. 1825.", "Barleria longifolia L., Amoen. Acad. 4: 320. 1759.", "Barleria auriculata Schumach., Beskr. Guin. Pl. 285. 1827.", and "Hygropbila auriculata (Schumach.) Heine, Kew Bull. 16: 172. 1962." Unfortunately, the status of "B. schulli" has been in dispute (invalid or illegitimate), and either way, it cannot serve as a basionym. Therefore, $H$. schulli was superfluous and illegitimate, when published. Therefore, "H. schulli var. alba Parmar" cannot be used as an accepted name.

Based on the USDA treats, $H$. schulli act as a synonym of H. auriculata (Schumach.) Heine (Kew Bull. 16: 172. 1962). Then we can resolve the problem by proposing a new combination to the taxa viz, Hygrophila auriculata (K. Schum.) Heine var. alba (Parmar) P. M. Salim, J.Mathew \& Yohannan comb. nova.

Hygrophila auriculata (K. Schum.) Heine var. alba (Parmar) P.M.Salim, J.Mathew \& Yohannan comb. nova.

Hygropbila schulli M. R. Almeida \& S.M. Almeida var. alba Parmar, J. Econ. Taxon. Bot. 32(1): 149. 2008.

Type: INDIA, Gujarat, Mehsana, from stagnated rain water in swampy habitat near Kadi, Kanajari, 30 sept. 2003, P.J. Parmar 12988 (Holo: CAL!; Iso: BSJO! 12988).

Perennials to $2 \mathrm{~m}$ tall, unbranched, rooting at lower nodes. Stems erect, hispid, imperfectly 4-angled, green, pubescent with white hairs. Internodes $3-3.6 \mathrm{~cm}$ long. Nodes pulvinous, thickly pubescent, with leaves and thorns. Thorns 6-8 per nodes, each with $2-2.6 \mathrm{~cm}$ in length. Leaves 6 in each nodes, whorled, Petiole 0.8-1 cm, pubescent; leaf blade linearlanceolate, light green, $10-20 \times 0.9-1.2 \mathrm{~cm}$ in size, both surfaces with numerous multicellular hairs, margins entire and sometimes undulate, apex acute-acuminate, base cuneate; primary veins $12-16$ pairs with creamy white-greenish white in colour. Flowers in axillary whorls, 6-8; bracts and bracteoles resembles leaves; bracts pale green, pubescent, $4-5 \mathrm{~mm}$ in length. Calyx narrowly campanulate, $c a .0 .7-1 \mathrm{~cm}$ in length, 4lobed, lobes linear-lanceolate, pubescent, apex acuminate. Corolla pure white, 5 lobed, 14-17 $\mathrm{mm} \times 4-6 \mathrm{~mm}$ in size, tube $10-13 \mathrm{~mm}$ x $2 \mathrm{~mm}$ wide, glabrous; limb 2-liped; upper lip bifid and lower lip trifid, acanthaceous mark field in ciliate with 3 $\mathrm{mm}$ length. Stamens 4, in didynamous, filaments glabrous, longer pair ca. 6-8 mm, shorter pair ca. 3-4 mm; anther slightly versatile, golden yellow, 2-3 mm. Ovary glabrous; style filiform, ca. $8 \mathrm{~mm}$; stigma simple, $2-2.2 \mathrm{~cm}$ in length. Capsule narrowly oblong, $0.8-2.2 \mathrm{~cm}$, ca. $1.5 \mathrm{~mm}$ wide, glabrous, 12-18-seeded. Seeds ca. 3 mm, pubescent. Fig. 3.

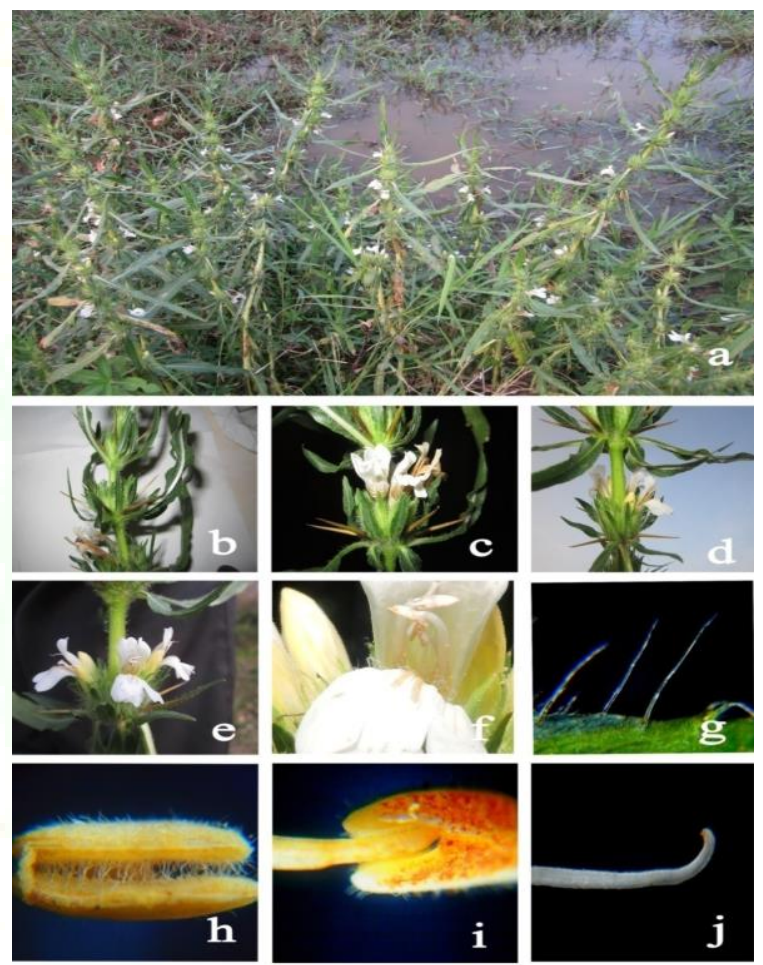

Fig. 3: Hygrophila auriculata (K. Schum.) Heine var. alba (Parmar) P.M. Salim, J.Mathew \& Yohannan: a. Plants in natural habitat; b, c, d \& e. Vegitative and flowering twigs; f. Acanthaceous mark regions with hairs; g. Multicellular hairs on leaves; h \& i. Stamen; j. Stigma. (a-f. Photographed by P.M. Salim, g-j. Photographed by R. Yohannan)

Flowering \& Fruiting: September- January

Distribution and ecology: Found in swampy habitats of stagnated rainwater (altitude $\pm 860 \mathrm{~m}$ ) of the Kuzhimoola vayals, $12 \mathrm{~km}$ away from Muthanga WLS, Wayanad, south Western Ghats, Kerala, India. It grows in associated with Lagenandra toxicaria Dalz. var. toxicaria Hook. f., Colocasia esculenta (L.) Schott, Cyanotis axillaris (L.) D. Don, Eleocharis retroflexa (Poir.) Urban ssp. chaetaria (Roem. \& Schult.) Koyama, Ludwigia hyssopifolia (G. Don) Exell and Paspalum scrobiculatum L.

Conservation status: Hygrophila auriculata var. alba is currently known from only six populations in Wayanad, separated by a distance of only $50-60 \mathrm{~m}$. A total of 150 mature individuals were found in the area. According to the IUCN categorization (IUCN 2012), the conservation status of this variety is data deficient. Further survey for this variety is suggested, which would need to be conducted in September to January when 
plants are flowering in order to differentiate it from the typical Hygrophila auriculata. Here, this taxon faces considerable pressure by habitat fragmentation, invasion of alien species and the scarcity of water.

Additional specimen examined: India: Kerala: South Western Ghats, Wayanad, Kuzhimoola near Muthanga, \pm 860 m, 15 Jan 2012, P.M. Salim 0405, 0406, 0407 (MSSRF!); 10 Feb 2016, R. Yohannan, 3116, 3117 (SN. College Herbarium, Kollam).

\section{Asystasia variabilis (Nees) Trimen}

Asystasia Blume, the genus has about 70 species distributed in the tropics of Old World (Mabberley, 2005; Chowdhery \& Bhattachaerjee, 2006). According to Sasidharan (2013), six taxa of Asystasia have been recorded from the Kerala part of the Western Ghats. Of which, Asystasia travancorica Bedd. is strictly endemic to the southern Western Ghats. While the floristic explorations in Kerala, we came across a small population of Asystasia characterized by a semi scandent, with elliptic lanceolate leaves and simple raceme at the semi evergreen forests of Peerumedu, near Periyar Tiger Reserve. After critical analysis of the literature as well as of herbarium specimens revealed that, these are belonging to Asystasia variabilis (Nees) Trimen, a spectacular taxon hitherto unknown from Kerala and India.

Critical note: In Flora of British India, Clarke proposed a new variety of Asytasia vir, Asystasia chelonoides var. quadrangularis. Subsequently, Gamble (1924); Mohanan (1984); Vajravelu (1990); Mohanan \& Henry (1994) are mentioned this plant from Kerala part of Western Ghats and Matthew (1991) from Tamil Nadu. Later, this taxon was reduced to synonymy of Asystasia chelonoides Nees without proper investigation of the type material. In the most recent treatment of the genus Asytasia in India, variety quadrangularis as belonging to Asystasia chelonoides Nees was continued (Sasidharan, 2013; GBIF, 2016).

On the other hand, a combination made in Handbook of Flora of Ceylon by Trimen in 1895 vi\%. Asystasia variabilis (Nees) Trimen (3:324) based on Ruellia variabilis and Asystasia gangetica var. variabilis to treat a Sri Lankan species. Now, this name is an accepted name but confined in the Sri Lanka. Critical examination on large number of herbarium sheets and pertinent literature revealed that, our specimen belonging to Asystasia variabilis. In fact, the south Indian quadrangularis variety and Sri Lankan $A$. variabilis are currently assigned to single taxon, Asystasia variabilis.

Asystasia variabilis (Nees) Trimen, Handb. Fl. Ceylon 3:325.1895.

Asystasia gangetica var. variabilis Nees in DC., Prod. 11: 165.1847 Asystasia chelanoides sensu Thw., Enum. Pl. Zeyl. 256. 1860 Asystasia nemorum Nees var. angustifolia Thw. Ex T. Anders., J. Linn. Soc. Bot. 9: 525. 1867

Asystasia chelanoides Nees var. quadrangularis Clarke in Hook.f., Fl. Br. Ind. 4: 494.1885

Stem erect at first upto $1 \mathrm{~m}$ high, then semi scandent, sharply grooved on opposite sides, slightly tumid above nodes. Leaves variable, linear-elliptic, to $12-20 \times 1.2-2.5 \mathrm{~cm}$, from an acute base tapering into petiole, tip acuminate, thinly hairy above, glabrous below, lateral veins $7-8$ pairs; petiole to $1.8 \mathrm{~cm}$. Raceme terminal, compact, 4-6 cm long; pedicel $1.5 \mathrm{~mm}$, bracteoles similar linear, c. $0.5 \mathrm{~cm}$ long, green, acute, pubescent, persistent. Calyx divided to the base or nearly so, lobes 5, linear-lanceolate, 6-8 $\mathrm{mm}$ long, acute, densely pubescent on both surface. Corolla tube funnel- shaped, 0.9-
$1.5 \mathrm{~cm}$ long, bent at base, pubescent, pinkish-violet, lobes 5, ovate oblong, 6-7 x 4-5 mm, lower midlobe broderwith two raised ridges. Stamens 4, didynamous, included, filaments 5-7 $\mathrm{mm}$ long, with few small hairs, connate at the base in pairs; anthers oblong, 2-3 mm long. Ovary c. $2 \mathrm{~cm}$ long, pubescent, 2 celled, ovules 2 in each cell; style linear, 1.5-1.8 cm long, basal portion hairy; stigma 2 -fid or subcapitate. Capsule clavate shaped, $2-2.5 \times 0.3-0.4 \mathrm{~cm}$, densely pubescent, opening widely in a reflexed curve; seeds $4,3-4 \mathrm{~mm}$ across, compressed angular, orbicular. Fig. 4.

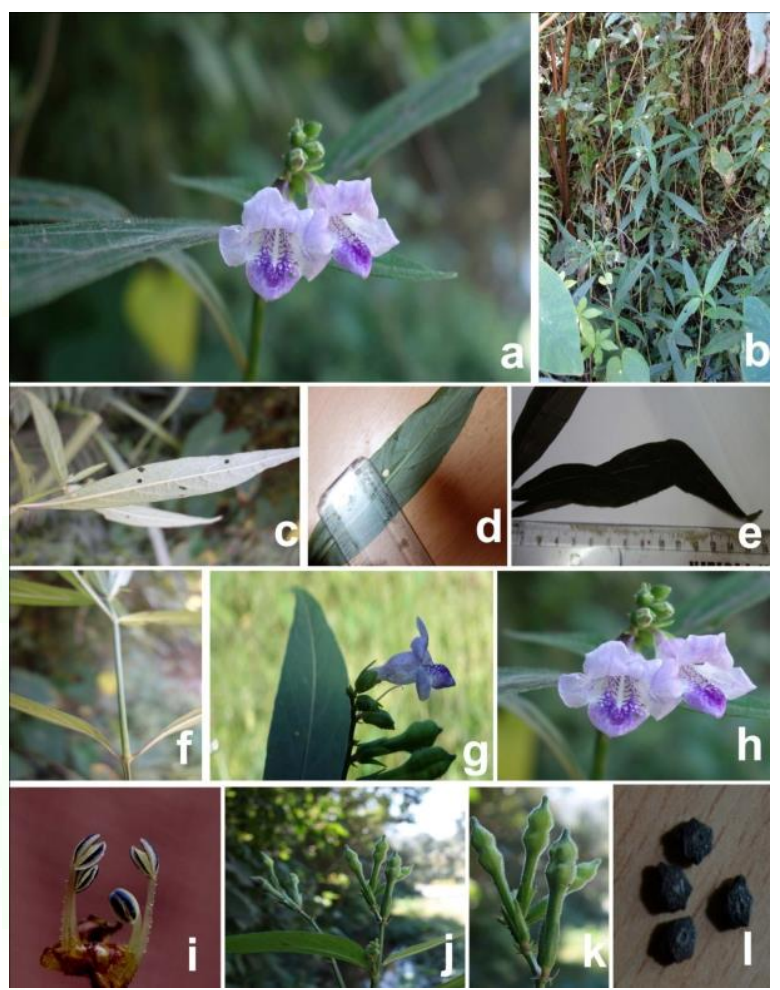

Fig. 4: Asystasia variabilis (Nees) Trimen: a. Flowering twig; b. In habitat, c, d \& e. Leaves; f. Stem; g \& h. Flowers in inflorescence; i. Stamen; $j$ \& k. Infruitescence; 1. Seeds (Photographed by J.Mathew).

Flowering \& Fruiting: August- March

Distribution and ecology: Found in semi evergreen forests (altitude $\pm 1050 \mathrm{~m}$ ) of the Peerumedu, $50 \mathrm{~km}$ away from Periyar Tiger Reserve, Idukki, south Western Ghats, Kerala, India. A small population of 30 plants were grows in associated with Dicliptera cuneata Nees, Lepidagathis incurva Buch. -Ham. ex D. Don var. incurva Manilal \& Sivar., Grewia serrulata DC., Celastrus paniculatus Willd. and Colocasia esculenta (L.) Schott.

Table 3: Characteristics that separate Asystasia variabilis from Asystasia chelanoides

\begin{tabular}{|c|c|c|}
\hline $\begin{array}{l}\text { Character } \\
\text { Habit }\end{array}$ & $\begin{array}{l}\text { A. variabilis } \\
\text { semi scandent, } \\
\text { upto } 2.5 \mathrm{~m} \text { long }\end{array}$ & $\begin{array}{l}\text { A. chelanoides } \\
\text { erect, } \\
1 \mathrm{~m} \text { long }\end{array}$ \\
\hline \multicolumn{3}{|l|}{ Leaf } \\
\hline form & linear- elliptical & ovate to oval elliptic \\
\hline $\begin{array}{l}\text { size } \\
\text { hairs }\end{array}$ & $\begin{array}{l}12-20 \times 1.2-2.5 \mathrm{~cm} \\
\text { present in } \\
\text { in upper surface }\end{array}$ & $\begin{array}{l}5-12 \times 2.1-4.5 \mathrm{~cm} \\
\text { absent in both surfac }\end{array}$ \\
\hline \multicolumn{3}{|l|}{ Inflorescence } \\
\hline form & raceme & panicle \\
\hline length & $4-6 \mathrm{~cm}$ & $6-16.5$ \\
\hline Bracts, bracteoles & linear ovate & \\
\hline Corolla lobes & ovate-oblong & rounded \\
\hline
\end{tabular}


Specimes examined: INDIA. Tamil Nadu: On the way to Melpet-Javadi hills, 880 m.a.s.l., 01-02-1986, MB Vishwanathan 152867 (MH!); Near Papanasam falls, 800 m.a.s.l., 14-10-1958, K Subramanyan 13633 \& 13634 (MH!); Yercaud, Kiliyur waterfalls, 1380 m.a.s.l., 02-08-1966, S Kartbikeyan 56551 (MH!); Yercaud, Kiliyur waterfalls, 1380 m.a.s.l., 02-08-1966, $S$ Karthikeyan 56551 \& 56552 (MH!); On the way to Kambukudy, 900 m.a.s.l., 08-09-1958, K Subramanyan 12705 \& 12706 (MH!); Kerala: Pamba, 1025 m.a.s.l., 24-06-1968, DB Deb 58007 \& 58007 (MH!); Kuttikanam, Peerumaed, 1022 m.a.s.l., 23-111967, K Vivekanandan 59781 \& 59781 (MH!); Idukki to Kattapana, 900 m.a.s.l., 26-09-1981, CN Mohanan \& B Ramanujam 137725 (MH!); Pindimedu, Pooyamkutty, 75 m.a.s.l., 24-12-1988, P Bhargavan 149304 (MH!); Near the foothills of Agasthyamalai, 900 m.a.s.l., 05-10-1973, J Joseph 85990 (MH!); Kottur RF, 150 m.a.s.l., 25-09-1973, J Joseph 80863 (MH!); Kuttikanam, Peerumaed, 1025 m.a.s.l., 20-112014, J.Mathew 5123-5127 (SESH!).

\section{Acknowledgement}

The authors are grateful to the Kerala Forest Department for permission to conduct research. The first author wishes to thank the curator of TBGT, MSSRF and the anonymous reviewers for helpful comments on the manuscript. He is also grateful to Dr. K. N. Gandhi, Harward University, America for suggestions and encouragement. The second author is thankful to Dr. V. Devipriya, Associate Professor, Department of Botany, SN College, Chempazanthy, Kerala, for encouragement. The third author expresses his gratitude to the Director, MSSRF, Wayanad for support.

\section{References}

1. Almeida MR and SM Almeida, Identity of "Bahel schulli" of Hortus Malabaricus. Journal of Bombay Natural History society 83(1986): 221.

2. Chowdhery $\mathrm{H}$ and $\mathrm{A}$ Bhattacharjee, $\mathrm{A}$ new species of the genus Asystasia (Acanthaceae) Blume from West Bengal, India. Indian Journal of Forestry 29.2(2006): 211-215.

3. Gamble JS and CEC Fischer, The Flora of the Presidency of Madras. Adlard \& Sons Ltd., London, 1924.

4. GBIF, Global Biodiversity Information Facility. GBIF secretariat, Denmark, Digital resource at www.gbif.org, 2016.

5. IUCN, IUCN Red List Categories and Criteria. IUCN, Species survival commision, Gland, Switzerland and Cambridge, UK. 2012, Version 3.1. Second Edition.

6. Jiaqi $\mathrm{H}$, Yunfei D and Daniel DF, Acanthaceae: Hygrophila. In: Wu ZY, Raven PH, Hong DY (Eds.) Flora of China. Missouri Botanical Garden Press, St. Louis, USA. 2009, Vol. 19, pp. 430-432.
7. Karthikeyan S, Sanjappa M and M Moorthy, Flowering Plants of India-Dicotyledons. Acanthaceae-Avicenniaceae. Volume I, Botanical Survey of India, Kolkata. 2009, pp 1-4.

8. Mabberley DL, The plant book. Cambridge, UK: Cambridge University Press. 2005, 2nd ed., pp XVI + 858.

9. Manilal KS, Hortus Malbaricus (Eng.), Vol. 2. University of Kerala. Thiruvananthapuram, Kerala, India. 2003, p 163.

10. Mathew J and KV George, Hygropbila ringens ssp. longifolium (Acanthaceae): A new taxa from southern Western Ghats, India. International Journal of Advanced Research 1.9 (2013): 132-134.

11. Matthew KM, An excursion flora of Central Tamilnadu, India. Oxford \& IBH Pub. Co., New Delhi, 1991, p 647

12. Mohanan CN, Studies on the flora of Quilon District, Kerala. Ph.D. Thesis, Madras University, Madras, 1984.

13. Mohanan M and AN Henry, Flora of Thiruvananthapuram. Botanical Survey of India, Calcutta, 1994.

14. Parmar PJ, A new variety of Hygropbila schulli (Hamilton) M.R. Almeida \& S.M. Almeida from Gujarat, India. Journal of Economic and Txonomic Botany 32(2008): 149-150.

15. Rheede HAV, Hortus Malabaricus Vol. 2. Amsterdam, 1679, pp 87-88.

16. Roskov Y, Kunze T, Orrell T, Abucay L, Paglinawan L, Culham A, Bailly N, Kirk P, Bourgoin T, Baillargeon G, Decock W, De Wever A and Didžiulis (eds.) Species 2000 \& ITIS Catalogue of Life, 17th March 2014, Digital resource at www.catalogueoflife.org/col. Species 2000: Naturalis, Leiden, the Netherlands.

17. Sasidharan N, Flowering plants of Kerala: CD-ROM. Version 2.0. Kerala Forest Research Institute, Peechi, Kerala, India, 2013.

18. Vajravelu E, Flora of Palghat District. Botanical Survey of India, Calcutta, 1990.

\section{Cite this article as:}

Jose Mathew, Regy Yohannan, P.M. Salim and K.V. George. Novelties in the family Acanthaceae from south Western Ghats, India. Annals of Plant Sciences 6.01 (2017): 1499-1503.

DOI: http://dx.doi.org/10.21746/aps.2017.01.003 